\title{
2 Von der Marginalisierung von Land zum Land Rush
}

Der Ansturm auf Land in den späten 2000er Jahren kam als Überraschung in einer Zeit, die in den Regionalstudien zumeist als „post-ländlich“ und „post-produktivistisch" charakterisiert wurde, und in der ländliche Lebensweisen und Existenzsicherungen (einschließlich der von Landwirten) zunehmend als multifunktional, transient oder sogar „hyperreal“ beschrieben wurden. ${ }^{1}$ Die Frage „Was ist Land?“ wurde seit den 1970er Jahren in der sozialwissenschaftlichen Erforschung ländlicher Räume und den Agri-Food Studies kaum noch gestellt. Land als Forschungsobjekt rückte zunehmend in den Hintergrund oder wurde gänzlich ignoriert. ${ }^{2}$ Kurz vor Beginn des Land Rush ${ }^{3}$ konstatierte der Geograph Michael Woods, dass ländliche Politik - ,political debates concerning agriculture, or forestry, or the management of rural land more broadly“ - durch eine „Politik des Ländlichen“ ersetzt wurde, die vielmehr Themen wie ländliche Identität, Gemeinschaft und die Bedeutung und Regulierung von Ländlichkeit betrachtet. ${ }^{4}$ Die zunehmende Popularität von Warenkettenansätzen in der Erforschung ländlicher Räume seit den 1990er Jahren untermauerte diesen Trend, ${ }^{5}$ ebenso wie

1 P. Cloke, „Country Backwater to Virtual Village? Rural Studies and the ,Cultural Turn““, Journal of Rural Studies 13 (1997) 4, S. 367-376. - Die Darstellung der Debatte in diesem Abschnitt beruht in großen Teilen auf der Einleitung zum Sonderheft S. R. Sippel und O.Visser, „Reimagining Land. Materiality, Affect, and the uneven Trajectories of Land Transformation“, Agriculture and Human Values 38 (2021) 1, S. 271-282.

2 M. Mormont, „Who is Rural? Or, How to be Rural. Towards a Sociology of the Rural“, in: T. Marsden, P. Lowe, und S. Whatmore (Hrsg.), Rural Restructuring. Global Processes and their Responses, London: David Fulton Publishers, 1990, S. $21-44$.

3 Wir folgen in der Verwendung des Begriffs „Land Rush“ Li, die argumentiert „what is distinctive about the intensified interest in global farmland since 2008 is its temporality and scope, not the mechanisms, processes or impacts of land acquisition, which have a long history. [T]he characteristic feature of a rush is a sudden, hyped interest in a resource because of its newly enhanced value, and the spectacular riches it promises to investors who get into the business early. Hence the rush.“ T. M. Li, „What is Land? Assembling a Resource for Global Investment“, Transactions of the Institute of British Geographers 39 (2014) 4, S. 589-602, hier S. 594.

4 M. Woods, „Redefining the ,Rural Question'. The New ,Politics of the Rural' and Social Policy“, Social Policy and Administration 40 (2006) 6, S. 579-595, hier S. 580.

5 A. Hughes und S. Reimer (Hrsg.), Geographies of Commodity Chains, London: Routledge, 2004; N. Fold und B. Pritchard (Hrsg.), Cross-Continental Agro-food Chains. Structures, Actors, and Dynamics in the Global Food System, London: Routledge, 2005; L. J. Pegler, „Peasant Inclusion in Global Value Chains. Economic Upgrading but Social Downgrading in Labour Processes?“, Journal of Peasant Studies 42 (2015) 5, S. 929-956; J. Neilson und B. Pritchard, Value Chain 
der Fokus auf die Erforschung ländlicher Mobilitäten. ${ }^{6}$ Je mehr globale Verflechtungen, Vernetzungen und Flüsse in den Blick genommen wurden, desto stärker rückten die Landwirtschaft und ihre Einbettung in lokale Umweltzusammenhänge in den Hintergrund.

Dieser Wandel weg von „ländlicher Politik“ war in der Erforschung ländlicher Räume des Globalen Nordens (Europa, Nordamerika, Australien, Neuseeland) prägnanter als in Kontexten des Globalen Südens, wo die Existenzsicherung ländlicher Bevölkerungen nach wie vor stärker an Land und Landwirtschaft gebunden ist. Zwar wurden auch hier nicht-landwirtschaftliche Einkünfte aus Lohnarbeit und Rücküberweisungen zunehmend bedeutsam, landwirtschaftliche Tätigkeiten blieben jedoch im Vergleich zu Kontexten des Globalen Nordens von größerer Bedeutung. Entsprechend war der Rückgang der Bedeutung von Land in der Forschung zu Kleinbäuer:innen, ländlichen Bewegungen und Landreformen im Globalen Süden weniger ausgeprägt. Allerdings wurde Land hier überwiegend im Zusammenhang mit Landtransformationen und Prozessen der Akkumulation und Enteignung diskutiert. Spezifische Beziehungen mit und Verständnisse von Land wurden oftmals mehr vorausgesetzt als tatsächlich untersucht. So wurde Land in der Untersuchung von Landreformen überwiegend aus einer Eigentumsund Zugangsperspektive betrachtet. Andere Beziehungen zu Land spielten kaum eine Rolle. Diese „anderen“, vor allem nicht-eigentumsbasierten Beziehungen zu Land wurden vor allem in ethnologischen Studien zu indigenen Bevölkerungen und im Kontext der Verflechtungen zwischen Land und kolonialer Besetzung, Enteignung und indigenen Kämpfen um Landrechte und Selbstbestimmung untersucht. ${ }^{7}$ Im Ergebnis, so lässt sich zusammenfassen, wurde Land also über mehrere Jahrzehnte hinweg entweder ignoriert oder aber im Zusammenhang mit den „Anderen“, wie indigenen Bevölkerungen oder Kleinbäuer:innen, diskutiert.

Auch in den Literatursträngen, die sich seit Beginn der 1990er Jahre verstärkt mit Fragen von Landschaft (landscape) befasst haben, spielt Land kaum eine

Struggles. Institutions and Governance in the Plantation Districts of South India, Malden (MA): Wiley, 2011.

6 J. Gertel und S. R. Sippel (Hrsg.), Seasonal Workers in Mediterranean Agriculture. The Social Costs of Eating Fresh, London: Routledge, 2014; A. Corrado, C. de Castro, und D. Perrotta (Hrsg.), Migration and Agriculture. Mobility and Change in the Mediterranean Area, London: Routledge, 2016.

7 Siehe M. Tomlinson, „Sacred Soil in Kadavu, Fiji“, Oceania 72 (2002) 4, S. 237-257; N. BarreraBassols uind A. Zinck, „,Land Moves and Behaves': Indigenous Discourse on Sustainable Land Management in Pichataro, Patzcuaro Basin, Mexico“, Geografiska Annaler: Series A, Physical Geography 85 (2003) 3-4, S. 229-245. 
Rolle. ${ }^{8}$ Hier wurden neue Perspektiven auf die Wechselbeziehungen zwischen menschlichen und nicht-menschlichen Akteur:innen entwickelt, z. B. als neue

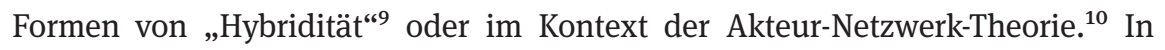
diesem neueren Feld der Mensch-Umwelt-Beziehungen entstanden zahlreiche Arbeiten zu Flora (u. a. Bäumen, Grenzpflanzen, Kulturpflanzen) ${ }^{11}$, Tieren ${ }^{12}$ und sogar Pilzen und Bakterien. ${ }^{13}$ Land (und Boden) blieben jedoch weitgehend ausgespart. Auch die Literatur zu Landschaft befasste sich mehr mit scapes denn mit Land, ${ }^{14}$ wie die zahlreichen Verwendungen von scape-Begriffen illustrieren von countryscapes und streetscapes ${ }^{15}$ hin zu lifescapes ${ }^{16}$ und dreamscapes. ${ }^{17}$ Kurz,

8 Siehe S. Daniels und D. Cosgrove, „Spectacle and Text. Landscape Metaphors in Cultural Geography“, in: J. Duncan und D. Ley (Hrsg.), Place/Culture/Representation, London: Routledge, 1993, S. 57-77; C. Gosden und L. Head, „Landscape - A Usefully Ambiguous Concept“, Archaeology in Oceania 29 (1994) 3, S. 113-116; S. Schama, Landscape and Memory, New York: A. Knopf, 1995; Cloke, „Country Backwater“; L. Head, Cultural Landscapes and Environmental Change, London: Routledge, 2000.

9 D. Haraway, Simians, Cyborgs, and Women. The Reinvention of Nature. New York: Routledge, 1991; S. Whatmore, Hybrid Geographies. Natures Cultures Spaces. London: Sage, 2002.

10 M. Callon, J. Law, und A. Rip, Mapping the Dynamics of Science and Technology. Sociology of Science in the Real World, Basingstoke: Macmillan, 1986; B. Latour, We Have Never Been Modern, Cambridge: Harvard University Press, 1993.

11 F. Heuts und A. Mol, „What is a Good Tomato? A Case of Valuing in Practice“, Valuation Studies 1 (2013) 2, S. 125-146; S. J. Martin, „The Political Economy of Distillers' Grains and the Frictions of Consumption“, Environmental Politics 29 (2020) 2, S. 297-316.

12 K. Saltzman, L. Head und M. Stenseke, „Do Cows Belong in Nature? The Cultural Basis of Agriculture in Sweden and Australia“, Journal of Rural Studies 27 (2011) 1, S. 54-62; L. Holloway u. a., „Animals, Technologies and People in Rural Spaces. Introduction to a Special Issue on Emerging Geographies of Animal-technology Co-productions“, Journal of Rural Studies 33 (2014), S. 95-98.

13 A. Tsing, The Mushroom at the End of the World, Princeton (NJ): Princeton University Press, 2018; J. Lorimer, The Probiotic Planet. Using Life to Manage Life. Chicago: University of Minnesota Press, 2020.

$14 \mathrm{Zu}$ Ausnahmen siehe die anthropologische Studie von Peace, die sich speziell des Landes und der Landschaft annimmt, sowie die Studien von Puig de la Bellacasa und Krzywoszynska: A. Peace, „A Sense of Place, a Place of Senses. Land and Landscape in the West of Ireland“, Journal of Anthropological Research 61 (2005) 4, S. 495 -512; M. Puig de la Bellacasa, „Making Time for Soil. Technoscientific Futurity and the Pace of Care“, Social Studies of Science 45 (2015) 5, S. 691716; A. Krzywoszynska, „Caring for Soil Life in the Anthropocene. The Role of Attentiveness in More-than-human Ethics“, Transactions of the Institute of British Geographers 44 (2019) 4, S. 661 675.

15 Cloke, „Country Backwater“.

16 I. Convery u. a., „Death in the Wrong Place? Emotional Geographies of the UK 2001 Foot and Mouth Disease Epidemic“, Journal of Rural Studies 21 (2005) 1, S. 99-109. 
diese neueren Studien blickten mehr auf die Diversität von more-than-human Akteuren und ihre Neu- und Ausgestaltung ländlicher Räume. Polit-ökonomische Dimensionen, die Land und Landschaft prägen, rückten zugunsten der Komplexität dieser Akteursbeziehungen in den Hintergrund. ${ }^{18}$

Die Land Rush-Literatur brachte ländliche Politik machtvoll zurück - und dies nicht allein im Globalen Süden, sondern auch und besonders im Globalen Norden. Dabei kamen vorwiegend etablierte Konzepte wie Kommodifizierung, (neue) Einhegungen (new enclosures) und Akkumulation durch Enteignung (accumulation by dispossession) zur Anwendung. Die Literaturstränge zu Landschaft, more-than-human natures und ,anderen“ Beziehungen mit Land wurden nicht berücksichtigt. Insbesondere in den ersten Jahren der Land Rush-Debatte ging es vorwiegend darum, das Ausmaß globaler Landnahmen durch multinationale Konzerne, Finanzakteure und Staaten zu dokumentieren. ${ }^{19}$ Dabei ergaben sich allerdings auch diverse konzeptionelle und methodologische Probleme, die von der Diversität und Fluididät in der Definition des Phänomens „Landnahme“ bis hin zum Mangel an mit sozialwissenschaftlichen Methoden erhobenen empirischen Daten reichten, da zahlreiche Publikationen auf der Basis von Medienberichten erstellt wurden. ${ }^{20}$ Auch halfen die polit-ökonomischen Konzepte der Einhegung und Akkumulation durch Enteignung zwar, globale Dynamiken und Mechanismen des Land Rush nachzuvollziehen, regionale Ungleichheiten und unterschiedliche ortsspezifische Entfaltungen von Landtransformationen wurden allerdings oftmals übergangen. Die „zweite Welle“ der Land Rush-Forschung zielte daher darauf ab, längerfristige empirische Studien durchzuführen und verschiedene historische Kontexte einzubeziehen, um der Situiertheit und Multiplizität von Akteur:innen und ihren Beziehungen zu Land besser gerecht $\mathrm{zu}$ werden. In der jüngeren Vergangenheit sind einige Arbeiten entstanden, die ein differenzierteres Bild der Ungleichzeitigkeiten, Komplikationen und Widersprüchlichkeiten innerhalb aktueller Landtransformationen zeichnen. ${ }^{21}$

17 K.A. Jaenke, Personal Dreamscapes as Ancestral Landscape, San Francisco: California Institute of Integral Studies, 2001, $\mathrm{PhD}$ dissertation.

18 P. McCall Howard, „The Anthropology of Human-Environment Relations. Materialism with and without Marxism“, Focaal 82 (2018), S. 64-79.

19 S. M. Borras u. a., „Towards a Better Understanding of Global Land Grabbing. An Editorial Introduction“, Journal of Peasant Studies 38 (2011) 2, S. 209-216; L. Cotula, „The International Political Economy of the Global Land Rush. A Critical Appraisal of Trends, Scale, Geography, and Drivers“, Journal of Peasant Studies 39 (2012) 3-4, S. 649-680.

20 M. Edelman, „Messy Hectares. Questions about the Epistemology of Land Grabbing Data“, Journal of Peasant Studies 40 (2013) 3, S. 485-501.

21 Siehe u. a. S. Ouma, „Situating Global Finance in the Land Rush Debate. A Critical Review“, Geoforum 57 (2014), S. 162-166; R. Pedersen und L. Buur, „Beyond Land Grabbing. Old Morals and 
Auf dieser Literatur aufbauend legen wir nachfolgend das Augenmerk auf die Verräumlichungspraktiken, die mit diesen Landtransformationen einhergehen. Hierfür skizzieren wir zunächst einen Analyserahmen für die Untersuchung von Land und Praktiken der (Neu-)Verräumlichung.

New Perspectives on Contemporary Investments“, Geoforum 72 (2016), S. 77-81; J. E. Goldstein und J. S. Yates, „Introduction. Rendering Land Investable“, Geoforum 82 (2017), S. 209-211; L. Schoenberger, D. Hall und P. Vandergeest, „What happened when the Land Grab came to Southeast Asia?“, Journal of Peasant Studies 44 (2017) 4, S. 697-725; P. Le Billon und M. Sommerville, „Landing Capital and Assembling ,Investable Land“ in the Extractive and Agricultural Sectors“, Geoforum 82 (2017), S. 212-224, hier S. 214; Sippel und Visser, „Reimagining Land“. 